\title{
The Implementation of Higher Education Funding in Indonesia
}

\author{
Dwi Priyono', Ahmad² \\ ${ }^{1}$ Muhammadiyah Prof. Dr. Hamka University, Jakarta, Indonesia \\ ${ }^{2}$ Universitas Gajayana, Malang, Indonesia \\ Email:dwipriyono@uhamka.ac.id,ahmad_t@unigamalang.ac.id
}

How to cite this paper: Priyono, D. and Ahmad (2018) The Implementation of Higher Education Funding in Indonesia. Open Access Library Journal, 5: e4049. https://doi.org/10.4236/oalib.1104049

Received: October 20, 2017

Accepted: June 5, 2018

Published: June 8, 2018

Copyright (C) 2018 by authors and Open Access Library Inc.

This work is licensed under the Creative Commons Attribution International License (CC BY 4.0).

http://creativecommons.org/licenses/by/4.0/

Open Access

\begin{abstract}
This study aims to determine the Implementation of Higher Education Financing in Indonesia which focuses on the accountability and transparency of higher education budgets management. The survey research was conducted at universities spread across the Sumatra and Java islands from October 2012 to October 2013, and proportionally selected 8 universities as sampling which were categorized as Applied Science-Technology and Educational Universities based. Data were analyzed by descriptive statistic technique and narrative descriptive technique using an approach popularized by Miles and Huberman. The study concluded that: 1) planning and budgeting system of higher education is carried out by centralization system, making it relatively easy for coordinating and consolidating policies and implementing higher education budget, 2) college policy autonomy in the management and implementation of Tri Darma of Higher Education authorizes Head of Higher Education to specify the orientation of university programs and activities, and 3) university's system and management mechanism, particularly the pattern of the planning and allocating budgets and costs, have to be continued to be updated to avoid commercialization of higher education. In general, higher education funding synchronization significantly affects the quality of higher education.
\end{abstract}

\section{Subject Areas}

Education

\section{Keywords}

Implementation, Funding, Higher Education, Quality, Universities

\section{Introduction}

Universities as institutions providing higher education have a strategic role in 
producing intellectuals, scientists and creative professionals who are culturally conscious, tolerant, democratic, have a good character, and dare to defend the truth for the sake of the nation in the constellation of globalization in all fields [1] [2]. In 2012, the government has issued Law Number 12/2012 on Higher Education [3]. The law mandates a management system and delivery of Higher Education that is more professional and accountable. The mandate of the law divides the universities in Indonesia into two (2) types, namely State Universities (PTN), established and/or managed by the Government, and Private Universities (PTS), established and/or managed by private parties, in the form of an organizing body with a non-profit legal entity obtaining the permission from the Minister [3]. Referring to Law Number 12/2012 on Higher Education, there are roles and functions of universities, namely: 1) Places for learning Students and Society, 2) Media of education for future leaders, 3) Centers for the development of Science and Technology, 4) Centers of the study of virtue and morality to seek and find the truth, and 5) Centers for the nation's civilization development, which is generally integrated with the activities of Tri Darma of higher education. Tri Darma represents the visions of all universities in Indonesia which reflects the objectives that ought to be achieved. Through Tri Darma, the university is expected to be able to optimize its role to generate reliable and professional human resources. The program planning and activities of the universities and budgeting allocation are always aimed at meeting the Tri Darma of higher education.

The problems encountered in the implementation of higher education mainly related to cost of education management [4] [5] [6]. Moreover, the fundamental financial problems faced by institutions of higher education are worldwide and stem from two nearly universal forces [7]. The first of these is the high and increasing unit, or per-student, cost of higher education and second pressure for increasing enrollments, particularly where high birth rates are coupled with rapidly increasing proportions of youth finishing secondary school with legitimate aspirations for some tertiary education.

Let alone the regulation of education subsidiary funds revocation by the government which caused society burden more severe. This is forming another challenge of universities facing in the future on how to find sustainable financing solutions, one of which is by working with private parties to face the public investment reduction. Another strategy is by providing quality program services through the innovative programs expansions in accordance with the community needs.

In A Report by the Institute for Fiscal Studies, summarized the trends in fee rises and university income resulted in a sudden boost to university income, followed by subsequent flat-lining or declines in funding [8]. This has resulted in extremely high variation in funding per student over the past 30 years, which is unlikely to be optimal. However, it should be noted that the general trend is upwards, and that university funding per student is currently at the highest level it 
has ever been in the last 30 years.

The Institute for Fiscal Studies report upholds public tendency of the commercialization of higher education nowadays, that resulted in higher costs of university education, and making it difficult for the middle to lower class society to reach. The possession of Diploma, Bachelor and Postgraduate certificates becomes one of the requirements and guarantees to get a decent job, other than competence and work experience. This condition is shown by the low Gross Education Rate (GER) of Higher Education, which reached 26.34 percent in 2010 [9]. As a comparison, the university system in Europe, especially the one in Germany, is capable of providing free higher education despite the rapid shift to the US system that relies on community funding/contributions [10].

Both problems and challenges in higher education are the insalubrious organization of universities and their unwholesome autonomy and accountability that affect Indonesia's position, both regionally and internationally, because Indonesia has a strategic position as a bridge to the global market. The initiation of the ASEAN Community by 2015 would require an educated generation with good quality in terms of knowledge, skills and mental attitude.

The amendments to the Constitution of 1945 section 31 and Law on National Education System Number 20/2003 stipulating the obligation of the government to allocate education funding by at least 20 percent of the National Budget put the management and implementation of education into the spotlight [11]. Not only in the aspect of budget allocation, but also on the use of the budget in the implementation of education development in accordance with the national budget and revised-national budget. In addition, the public will also see the impact of the implementation of such development in changes in economic, social, and cultural practices in the country as a whole.

In each of the budgeting component, some sub-components have to be allocated when preparing the budget plan and the cost of higher education. The standard budget management and cost of higher education should be specifically defined up to the level of General Cost Unit, which can be used as a reference for university managers. The cost of education is the educational resources needed for management and organization of education [12]. Therefore, to calculate the cost of education, it is necessary to firstly identify the needs of educational resources (including qualifications or specifications and quantity) to manage and organize education in accordance with national education standards or minimum service standards [13].

Furthermore, the need for educational resources allocation takes place at governmental, institutional, and personal (parents/guardians of students) levels. Higher education is moving from being a public good, funded through government, to a private good where more of the cost is put on students and families [14].

The Directorate General of Higher Education has a number routine and strategic programs. Programs and activities should be continuously coordinated and monitored for the effectiveness and efficiency of their planning, implementation, 
monitoring and evaluation, and follow-up. Advantages and shortcomings in the implementation of these programs and activities will be taken into consideration for policy formulation and strategic implementation of educational development in the following year.

Therefore, the strategic steps must be done in order to develop higher education based on the three (3) pillars [15]: 1) provision of funds (scholarships) for poor families and those in needs, 2) development of the university management system that supports independency and accountability, and 3) provision of better education in the higher education system that is capable of meeting the needs of universities and companies and is able to handle cooperation with foreign universities [16].

To develop a proper budgeting system in higher education, funding issues ranging from planning and financing targets, determining budget allocation, and implementing the plans, need to be addressed. Budget effectiveness and efficiency of higher education must first be measured by the development plan, as outlined in a number of development plan documents, for example General Education Development Plan, Medium Term Development Plan, and Short Term Development Plan on the programs and activities of higher education. The development plans have a number of indicators of achievement and development targets, described as Key Performance Indicators (KPI). The KPI is further operationalized in Main Performance Indicators (IKU) and Activity Performance Indicator (IKK).

The amount of budget that should be allocated (in number and percentages) is set according to IKU and IKK, and then set as Budget Planning Entry List implemented in the current year. Therefore, it is necessary to do research on the Implementation of Higher Education Financing in Indonesia focusing on accountability and transparency of higher education budget management with the emphasis on synchronization between governmental policy and the direct implementation of education management fees by universities. Cost management is limited to operational costs for the welfare of employees, non-personnel operational cost, the cost for human resources improvement, and the cost of facilities and infrastructures, only for universities in Sumatera and Java island as the samples. The research is expected to provide a comprehensive overview on the condition and situation of education funding issues in Indonesia.

Theoretically, this research is expected to be beneficial to the development of the higher education financing studies, as well as can be used as a preliminary information to conduct more in-depth research especially related to higher education financing, due to several limitations in the generalization of this current research results caused by the condition of the region, the number and characteristics of the sample and the respondents. Practically, the results of this study can be used as input for policy-makers at the Directorate of Higher Education and the University level in planning, implementing, monitoring and evaluating the transparent and accountable higher education finance. 


\section{Research Method}

This survey-based research was conducted for 1 (one) year starting from October 2012-October 2013. Data collection was conducted at Science-Applied Technology and Educational University based which has a good category in educational financing management according to Directorate of Higher Education's standard. The location of the research university is spread on Sumatra and Java islands, and then selected 4 (four) universities in proportional sampling on each island namely: State University of Bengkulu, Dehasen University, $\mathrm{Mu}$ hammadiyah University of Bengkulu, Prof Dr Hazairin SH University, Gadjah Mada University, State University of Yogyakarta, Ahmad Dahlan University, and State Islamic University of Yogyakarta. From 8 (eight) universities, 32 respondents were selected from the head and staff of Administrative Bureau of Academic and Student Affairs (BAAK) or Bureau of Public Administration and Finance (BAUK) and involved in the Focus Group Discussion (FGD), questionnaires, and interviews conducted separately in accordance with the timing of the data collection. Data analysis techniques using descriptive statistics, meaning the data obtained is described by using the following percentage formula: Percentage of answers $=\mathrm{f} / \mathrm{n} \times 100 \% . \mathrm{F}=$ frequency of subjects choosing alternatives; $\mathrm{n}=$ total number of subjects [17], 2). Other analytical techniques of narrative descriptive with the approach pioneered by Miles, Huberman \& Saldaña [18] are applied through three paths: Data Reduction, Data Presentation, and Conclusion.

\section{Results and Discussions}

The improvement of the quality of higher education institutions could not be separated from the availability of funding sources and the expenditure of education budget. The sources of higher education budgets are among others the National Budget, Regional Budget, non-tax revenues, grants, independent funds, university business unit funds, and other types of funding. The sources of university budgets are shown in Table 1 .

Since 2009 to 2011, the funding sources are still dominated by the public aid, with a range of $28.79 \%$ to $30.21 \%$. Funding from public aid will be allocated to fund the following needs: 1) the need for educational operations (personnel costs, the cost of learning, other operating costs), 2) for education development, 3) investment (human resources, infrastructures and facilities), 4) research and community services, 5) scholarships/grants for underprivileged students, and 6) other educational activities. Based on these findings, it is actually not in accordance with the national education budget allocation that is increasing each year, as regulated in the Law of the Republic of Indonesia Number 20/2003, mandating the national education budget allocation of at least 20 percent of the total national budget.

Referring to the data of education budgeting needs at each level of education, 
Table 1. Sources of funding and absorption of education costs in universities.

\begin{tabular}{cccc}
\hline & Sources of Funding (\%) & & \\
Year & 2009 & 2010 & 2011 \\
National Budget & 19.7 & 11.2 & 10.4 \\
Regional Budget & 7.6 & 12.2 & 10.4 \\
PNBP/Non-tax revenue & 18.2 & 11.2 & 11.5 \\
Grants/Loans & 12.1 & 15.3 & 17.7 \\
Public assistance & 28.8 & 28.6 & 30.2 \\
College business unit & 9.1 & 11.2 & 11.5 \\
Other sources & 4.5 & 10.2 & 8.3 \\
\hline Year & Average Budgeting (\%) & & \\
Diploma & 2009 & 2010 & 2011 \\
Undergraduate & 0.79 & 0.16 & 0.45 \\
Postgraduate & 14.57 & 63.63 & 75.92 \\
\hline
\end{tabular}

Source: Analysis of Research Data, 2013.

the diplomas' budgeting needs seems to be more constant compared to the undergraduate and postgraduate levels. At the postgraduate education program, the budgeting needs tend to experience a significant decrease each year. It decreases from $84.64 \%$ in 2009 to $23.63 \%$ in 2011 , while in undergraduate education programs, it experiences an increase each year from $14.57 \%$ in 2009 to $75.92 \%$ in 2011 . This finding may be caused by several key factors, namely: 1) the weakness of monitoring and control function from the Directorate General of Higher Education in financing higher education policy, 2) multiple interpretations of regulations issued by the government, 3) the independently managed budgeting, 4) the high public interest in participating in undergraduate programs, with limited governmental attention, and 5) the length of time the study in the undergraduate program. Costs incurred by universities in the last three years $(2009,2010$, and 2011$)$ to finance the education process, such as registration fees, admission cost, tuition fee, the cost of semester credits, the cost of operational aid, and other costs, are described in Graph 1.

Based on the graph shown above, the costs incurred by the public to be enrolled in Diploma education program have increased steadily. The registration fee increases by $29.35 \%$, and admission fee increases by $21.71 \%$. At the undergraduate level, the cost of education in 2011 is increased compared to the previous years. Tuition fee increases by $27.54 \%$, semester credit payment increases by $40.17 \%$, and educational management fee increases by $30.57 \%$. Meanwhile, the postgraduate program until the year 2011, the cost of educational management fee increases by $32.30 \%$, and semester credit payment increases by $49.45 \%$. 


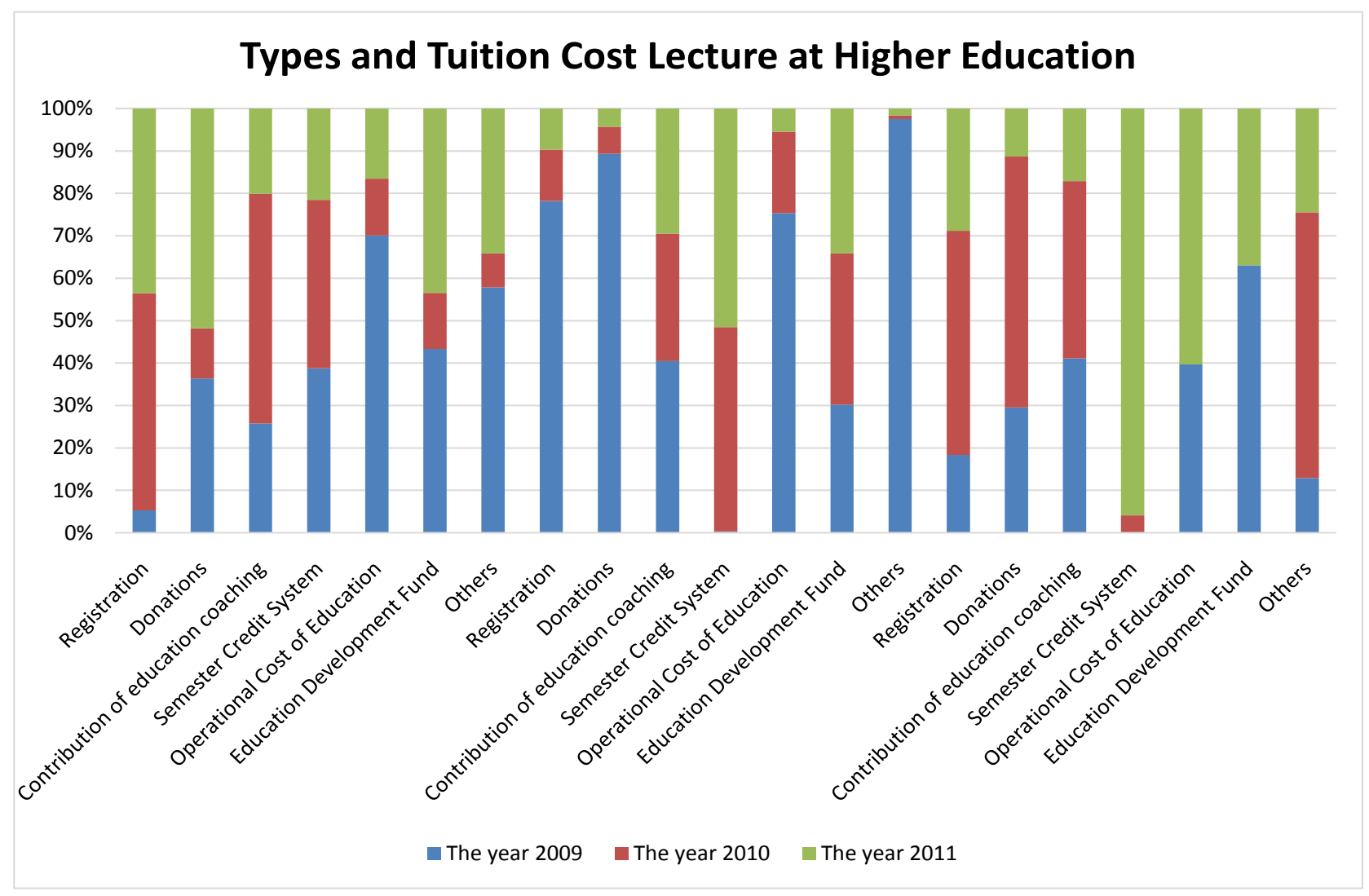

Graph 1. Education fees by program types. Source: Analysis of research data, 2013.

Facts show that most universities, both public and private, in Indonesia are still taking assistance from the community to support their education programs, even though public universities have been assisted by the government through Operational Aid for Public University program. In the implementation, the Operational Aid has not been able to cover the budget deficit of the universities, and not to mention, the universities feel burdened by bureaucratic procedures and stages, and the budget allocation is not in accordance with the needs of the universities.

These findings were confirmed by direct interview with the authors, along with some respondents. In conclusion, the earlier purpose of the Operational Aid for Public University is to cover the budget deficit of public universities, but then the universities are confused by the policy because there is no clear mechanism for budget channeling. Furthermore, the respondents said that the government should be able to differentiate the allocation of the subsidies between science-based universities (Gadjah Mada University, State University of Bengkulu, State Islamic University of Yogyakarta) with education-based universities (State University of Yogyakarta, Ahmad Dahlan University), meaning that the Operational Aid must be proportionally allocated. If not, universities must seek alternative additional funds source to cover operational costs.

A different condition is perceived by private universities, that independently 
manage the provision of higher education without interference from the government in managing the funds coming from the managers, the public and grants from institutions and collaborating partners as a locomotive for the provision of education. The lack of higher education cost allocation is assumed to inhibit the implementation of educational programs. The research shows that the biggest obstacles to implement educational programs are consistently influenced by elements of the funding, as shown in the following Graph 2.

Universities have essentially experienced obstacles in implementing educational programs, but among these problems, the funding, infrastructure, and human resources consistently affect the implementation of higher education programs. The results of this study indicate that the implementation of higher education programs decreases significantly each year, as shown in the implementation of university programs graph. The findings are also supported by the results of interviews stating that the program implementation in universities is constrained because of funding, quality of human resources, both the teachers and teaching personnel, as well as supporting infrastructures of the program that do not meet quality criteria.

Therefore, the government, in collaboration with universities, is improving infrastructures and facilities to support education, especially in Private Universities, so that the standard gap between state and private universities are not too big, because their graduates work for the public, and even the country. Thus, the provision of assistance should be done equally well for public and private universities, in addition to the need to formulate an operational basis in each of the programs developed and mechanisms for the budget formulation that need to consider the type of universities (research-based vs science-based). Other

\section{Constraints in Realizing the University Program (in percent)}

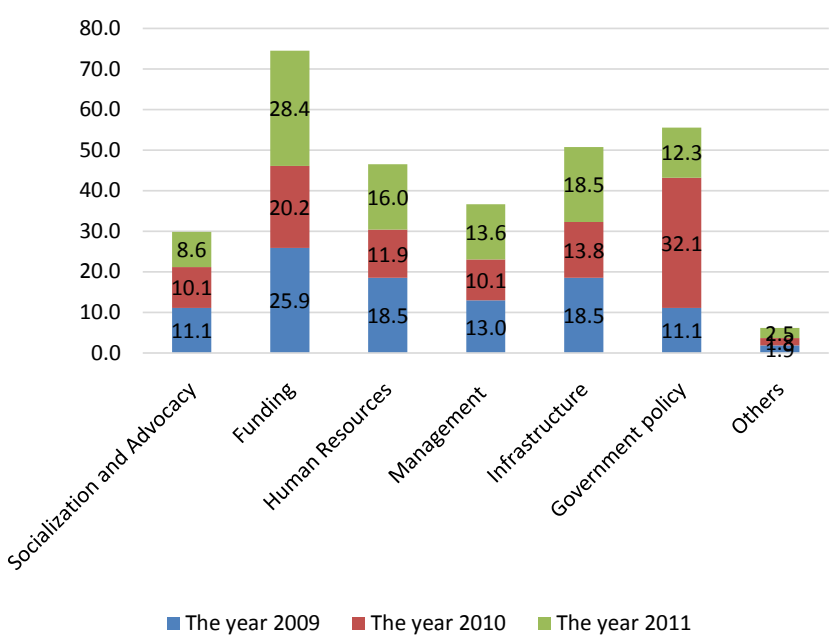

(a)

\section{Program Realization Based on Education Budget}

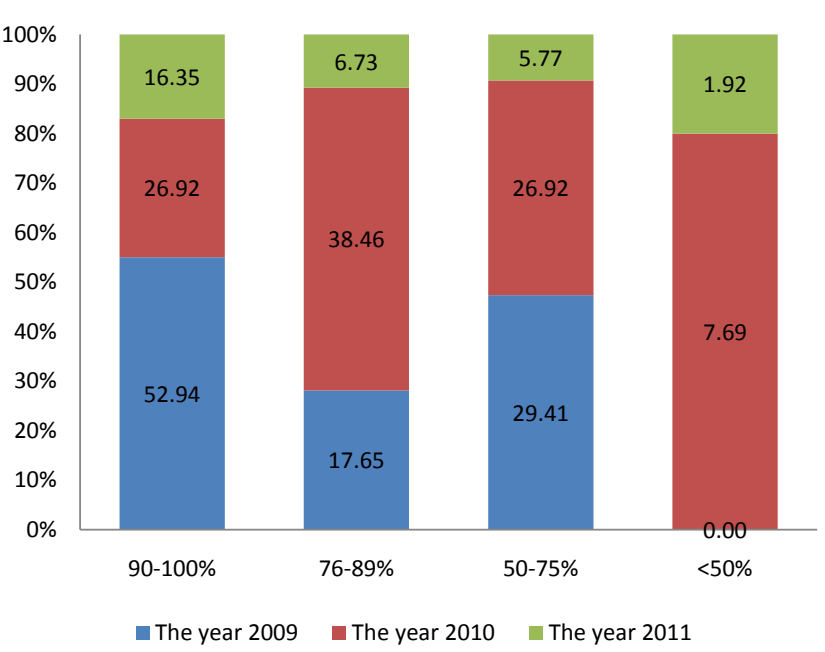

(b)

Graph 2. Obstacles and implementation of university programs. Source: Research Data Analysis, 2013. 
factors, such as policy concerning tuition fees restriction for the learners, while, on the other hand, many universities, both public and private, the main source of funding comes from the community, while making education requires a high budget. This condition is exacerbated by a variety of innovative government programs that require serious attention in their implementation, for example by giving scholarships, such as Scholarship for the Poor and Operational Aid programs.

From the result of the interview, the researchers conclude that the resource managers at universities organizing Scholarship for the Poor and Operational Aid experience constraints in implementing available budget, because the management manual of the budget is too general, whereas the budget is not enough to meet the needs of the universities. Thus, in the future, the government needs to give attention to the operational assistance programs, through sustained public and private universities (Operational Aids for Public/Private Universities) assistance to improve and develop the university programs.

\section{Conclusions}

The planning and budgeting system of higher education is carried out by the pattern of centralization (concentration), making it relatively easy for coordination, consolidation, and implementation of the higher education budget. The Directorate General of Higher Education as the manager of technical planning and implementation of higher education programs has direct authority to any state university and direct coordination with the private universities throughout Indonesia.

Campus autonomic policy in the management and implementation of the $\operatorname{Tr} i$ Darma of Higher Education authorizes the university management to define the orientation and program/activity respectively. Functionally, there are research-oriented campuses (Research Universities), for example Gadjah Mada University (UGM) and education-oriented campuses (former University of Teachers' Training College). These differences also affect the calculation of the general cost unit (SBU) which is used in the budget and costs preparation. University management systems and mechanisms, especially the pattern of the preparation and management of budgets and costs, have to continue to look for solutions and formulations. University management policy change in the form State Owned Legal Institute is considered as the commercialization of higher education by certain groups until terminated by the decision of the Constitutional Court (MK). Pioneering Operational Aid for Public Universities in 2012 is expected to reduce public's burden in financing higher education. Similarly, the plan to eliminate the registration cost to enter State Universities is very helpful for students from poor families.

\section{Recommendation}

Centralized policy in university budget and fees drafting as well as the granting of autonomy to universities in managing the budget and the cost of education 
are in conformity with the climate and the dynamics of universities to compete. The differences in campus' orientation, as a research campus, regular campus, and campus focusing on culture make it necessary to set the General Cost Unit that takes into account the orientation difference. The standard budget planning system and the cost of university need to be standardized, simultaneously controlled and evaluated in the form internal and external audit by the auditor (public accountant) to ensure the accountability of budget management by a university (both public and private). Efforts to reduce cost barriers to access to higher education must continue to be assessed by the government so that every citizen who has the potential and high academic competence can be developed by the universities. Registration fee exemption for Government Universities (and also private universities) needs to be done and supported by all parties until the GER of higher education continues to improve. To get a more comprehensive assessment results, further researches need to be done related to the variables that become the focus and locus of higher education funding.

\section{References}

[1] Kezar, A., Chambers, A.C. and Burkhardt, J.C. (2015) Higher Education for the Public Good: Emerging Voices from a National Movement. Jossey-Bass, San Francisco.

[2] Wexler, P. (2017) Social Analysis of Education: After the New Sociology. Routledge Library Editions: Sociology of Education. Routledge, London.

[3] Law Number 12 Year 2012 on Higher Education.

[4] Daniel, B. (2015) Big Data and Analytics in Higher Education: Opportunities and Challenges. British Journal of Educational Technology, 46, 904-920. https://doi.org/10.1111/bjet.12230

[5] Pucciarelli, F. and Kaplan, A. (2016) Competition and Strategy in Higher Education: Managing Complexity and Uncertainty. Business Horizons, 59, 311-320. https://doi.org/10.1016/j.bushor.2016.01.003

[6] Kaplan, A.M. and Haenlein, M. (2016) Higher Education and the Digital Revolution: About MOOCs, SPOCs, Social Media, and the Cookie Monster. Business Horizons, 59, 441-450. https://doi.org/10.1016/j.bushor.2016.03.008

[7] Johnstone, D.B. (2004) Higher Education Finance and Accessibility: Tuition Fees and Student Loans in Sub-Saharan Africa. Journal of JHEA/RESA, 2, 11-36.

[8] Belfield, C., Britton, J., Dearden, L. and Van der Erve, L. (2017) Higher Education Funding in England: Past, Present, and Options for the Future. The Institute for Fiscal Studies, London. https://doi.org/10.1920/BN.IFS.2017.BN0211

[9] Education Ministry Education and Culture Statistics Data Center (2011) National Education Data. Education Ministry Education and Culture Statistics Data Center, Jakarta.

[10] Santoso, D. (2008) Biaya Mahal Pendidikan Tinggi. Republika [Online]. http://republika.co.id/search/Biaya\%20Mahal\%20Pendidikan\%20Tinggi

[11] Law Number 20 of 2003 on National Education System.

[12] Ghozali, A. (2012) Sistem Pendanaan Pendidikan di Indonesia. National Seminar of Ikatan Sarjana Pendidikan Indonesia, Universitas Negeri Yogyakarta.

[13] Ghozali, A. (2012) Strategi Pembiayaandan Pendanaan Pendidikan Dasardan Me- 
nengahdi Indonesia. Coordination Activities of Basic Education Policy of Primary, Secondary and PAUDNI, Expert Staff Social and Economic Affairs Ministry of Education and Culture, Bogor.

[14] Kandiko, C. and Blackmore, P. (2010) Creating a 21st Century Curriculum: The Kings-Warwick Project. Warwick University/Kings College, Warwick.

[15] Supriadi, D. (2006) Satuan Biaya Pendidikan Dasardan Menengah. PT. Remaja Rosdakarya, Bandung.

[16] Observer Data (2011) Document Analysis Results on MoE Strategic Plan, Strategic Plan of Higher Education, Main Performance Indicators of Higher Education.

[17] Murwani, S. (2003) Statistika Terapan: Teknik Analisis Data. Program Pascasarjana Universitas Negeri Jakarta, Jakarta.

[18] Miles, M.B., Huberman, M. and Saldaña, J. (2013) Qualitative Data Analysis: A Methods Sourcebook. 3rd Edition, Sage Publication, Beverly Hills. 